\title{
PENGEMBANGAN MEDIA AJAR PADA MATA KULIAH PENGANTAR PENDIDIKAN KEJURUAN
}

\author{
Sapto Haryoko ${ }^{1}$, Hendra Jaya ${ }^{2}$ \\ Saptoharyoko27@gmail.com, hendra070982@gmail.com \\ 1,2 Jurusan Pendidikan Teknik Elektronika FT UNM
}

\begin{abstract}
Abstrak
Tujuan dalam penelitian ini adalah (1) untuk mengetahui tahapan pengembangan Media ajar pada mata kuliah Pengantar Pendidikan Kejuruan di Jurusan Pendidikan Teknik Elektronika FT Universitas Negeri Makassar, (2) untuk mengetahui kelayakan Media ajar pada mata kuliah pengantar Pendidikan Kejuruan di Jurusan Pendidikan Teknik Elektronika di FT Universitas Negeri Makassar. Jenis penelitian yang digunakan adalah penelitian dan pengembangan (Research and development) yang bertujuan untuk mengembangkan dan menghasilkan suatu produk. Desain pengembangan mengacu pada model pengembangan instruksional dari Atwi Suparman yang terdiri dari 3 tahap yaitu: tahap mengidentifikasi, tahap mengembangkan, dan tahap evaluasi. Subjek penelitian ini adalah mahasiswa jurusan pendidikan teknik elektronika, dosen ahli desain dan dosen ahli konten. Instrumen penelitian menggunakan metode wawancara. Hasil yang diperoleh dalam penelitian ini adalah pengembangan Media ajar mata kuliah Pengantar Pendidikan Kejuruan memberikan output berupa buku ajar mata kuliah Pengantar Pendidikan Kejuruan. Hasil validasi pada ahli desain mendapat rata-rata sebesar 3,72 di nyatakan dalam kategori baik (Layak). Hasil validasi pada ahli konten mendapat ratarata sebesar 2,87 di nyatakan dalam kategori cukup baik (Layak). Berdasarkan hasil validasi dan revisi, dapat diketahui bahwa Media ajar berupa buku ajar mata kuliah Pengantar Pendidikan Kejuruan dikatakan layak, untuk itu disarankan Media ajar ini dapat digunakan sebagai alat bantu dalam pembelajaran mata kuliah Pengantar Pendidikan Kejuruan.
\end{abstract}

Kata Kunci : Media Ajar, Buku Ajar, Pengantar Pendidikan Kejuruan

\begin{abstract}
The purpose of this research is (1) to know the stages of development of teaching materials in the course of Introduction of Vocational Education in the Department of Electronic Engineering Education at Makassar State University, (2) to know the eligibility of teaching materials in the introductory subject of Vocational Education in the Department of Electronic Engineering Education at Makassar public university. The type of research used is research and development (research and development) which aims to develop and produce a product. Freelance development design on instructional development model from Atwi Suparman consisting of 3 stages: prevention phase, development stage, and evaluation phase. The subjects of this study are students majoring in engineering electronics engineering, design lecturers and lecturers content experts. Research instrument by method. The results that are available in this research are the development of subject material of Introduction to Vocational Education giving the output of textbook introductory subject of Vocational Education. The results of validation on design experts got an average of 3.72 in declared in either
\end{abstract}


category (feasible). Validation results on content experts got an average of 2.87 in declared in good enough category (feasible). Based on the results of validation and revision, can be known. This teaching can be used as a tool in the introductory course of Vocational Education.

\section{Keywords: Teaching Materials, Textbooks, Introduction to Vocational Education}

\section{PENDAHULUAN}

Pada dasarnya pendidikan adalah usaha sadar dan terencana untuk mewujudkan suasana belajar dan proses pembelajaran agar peserta didik secara aktif mengembangkan potensi dirinya untuk memiliki kekuatan spiritual keagamaan, pengendalian diri, kepribadian, kecerdasan, akhlak mulia, serta keterampilan yang diperlukan dirinya, masyarakat, bangsa, dan negara (UU No. 12 Tahun 2012). Pendidikan akan membuat manusia mengembangkan potensi dirinya sehingga mampu menghadapi setiap perubahan yang terjadi akibat adanya kemajuan ilmu pengetahuan dan teknologi. Oleh karena itu, masalah pendidikan perlu mendapat perhatian dan penanganan yang lebih baik yang menyangkut berbagai masalah yang berkaitan dengan kuantitas, kualitas dan relevansinya.

Menurut para ahli mutu proses belajar mengajar diartikan sebagai mutu dari aktivitas mengajar yang dilakukan pendidik dan mutu aktivitas belajar yang dilakukan oleh peserta didik dikelas, laboratorium, bengkel kerja, dan kancah belajar lainnya (Abdul, 2012: 97). Sehingga proses belajar mengajar bermutu yang terjadi di kampus merupakan suatu kegiatan yang dilakukan di kelas yang harus ada unsur pengembangan sikap positif terhadap belajar, kerja, dan eksperimen serta pemecahan masalah.

Salah satu komponen yang mempengaruhi mutu proses dan hasil pembelajaran dilihat dari input, komponen proses, dan komponen output pendidikan dan pembelajaran.
Komponen input yang mempengaruhi mutu proses dan hasil pembelajaran di kelas secara mikro dan mutu pendidikan secara makro ialah komponen murid, siswa dan mahasiswa sebagai peserta didik yang akan diproses dalam kegiatan pembelajaran dan pendidikan (Abdul, 2012: 101). Komponen proses yang mempengaruhi mutu proses dan hasil pembelajaran di kelas adalah langkah yang diambil dalam proses pembelajaran dengan memanfaatkan masukan (input) dan suasana pembelajaran. Sedangkan komponen terakhir keluaran (output) adalah manusia (lulusan), produk/karya, dan jasa.

Seiring perkembangan zaman, kemampuan dosen dalam mengajar mengalami perubahan. Dosen adalah pendidik profesional dan ilmuwan dengan tugas utama mentransformasikan, mengembangkan, dan menyebarluaskan ilmu pengetahuan dan teknologi melalui pendidikan, penelitian, dan pengabdian masyarakat (UU No. 12 Tahun 2012). Jadi segala sesuatu yang berkaitan dengan kegiatan pembelajaran menjadi wewenang dan bertanggung jawab pendidik. Sumber belajar, metode dan Media ajar semuanya ada ditangan pendidik dalam artian pendidik sebagai fasilitator belajar peserta didiknya. Sebagai fasilitator tentu desain atau model pembelajaran tergantung pada bagaimana kreasi dari seorang pendidik, dalam hal ini yang tidak bisa terlupakan yaitu Media ajar.

Kebijakan pendidikan mengacu pada Standar Nasional Pendidikan (SNP) yaitu PP No. 19 Tahun 2005 
Pasal 20 yang berisikan bahwa pendidik diharapkan dapat mengembangkan materi pembelajaran, yang kemudian dipertegas melalui Peraturan Menteri Pendidikan Nasional (Permendiknas) Nomor 65 Tahun 2013 tentang standar proses, yang antara lain mengatur tentang perencanaan proses pembelajaran yang mensyaratkan bagi pendidik pada satuan pendidikan untuk mengembangkan Rencana Pelaksanaan Semester (RPS). Salah satu elemen dalam RPS adalah sumber belajar, yang termasuk Media ajar. Media ajar merupakan seperangkat materi yang disusun secara sistematis baik tertulis maupun tidak sehingga tercipta lingkungan atau suasana yang memungkinkan siswa untuk belajar.

Pelaksanaan pendidikan tinggi di Universitas Negeri Makassar (UNM) jurusan Pendidikan Teknik Elektronika (PTA) memiliki peran yang penting untuk mempersiapkan peserta didik agar siap menjadi pendidik yang baik. Lulusan UNM jurusan PTA harus memiliki kompetensi profesional selain kompetensi pedagogik. Kompetensi profesional yaitu kompetensi yang menguasai bidang elektronika.

Jurusan Pendidikan Teknik

Elektronika sudah didukung dengan komponen input, proses, dan output. Komponen proses berkaitan dengan kegiatan belajar dan mengajar di kelas maupun laboratorium atau bengkel kerja haruslah didukung dengan fasilitas belajar mengajar yang memadai. Hasil proses pembelajaran dipengaruhi fasilitas pembelajaran berupa gedung, peralatan belajar mengajar dan bahan ajar masih kurang dalam segi kualitas dan kuantitas. Sehingga ketersediaan Media ajar yang menjadi suatu kebutuhan untuk mencapai tujuan pembelajaran.

$$
\text { Media ajar merupakan }
$$

komponen penting dalam proses pembelajaran. Kehadiran Media ajar akan mempermudah dosen dalam menyampaikan materi pembelajaran dan mahasiswa lebih mudah dalam belajar. Media ajar ini bisa dibuat dan disusun sendiri oleh dosen pengampuh mata kuliah yang bertujuan agar Media ajar yang dihasilkan bisa menyesuaikan dengan kondisi mahasiswa.

Salah satu mata kuliah yang ada di jurusan Pendidikan Teknik Elektronika adalah mata kuliah pengantar pendidikan kejuruan. Pendidikan merupakan ilmu yang mempelajari tentang pengertian pendidikan dan ilmu pendidikan, unsurunsur pendidikan untuk menghasilkan suatu produk pendidikan.

Berdasarkan wawancara dengan pengampuh mata kuliah pengantar pendidikan kejuruan pada jurusan Pendidikan Teknik Elektronika FT UNM saat ini belum ada Media ajar yang khusus diterbitkan untuk pegangan mahasiswa dalam belajar. Buku-buku pelajaran yang ada di pasaran cenderung sangat umum materi ajarnya, sehingga kurang mendukung digunakan mahasiswa sebagai Media kajian materi pada proses pembelajaran. Selain itu, mahasiswa belum mempunyai lembar kerja mahasiswa yang digunakan untuk menjawab atau mengerjakan serta berlatih soal-soal tugas atau masalah yang harus dipecahkan.

Berdasarkan penjelasan dan permasalahan diatas, Media ajar mata kuliah pengantar pendidikan kejuruan sebagai alat bantu atau media yang sangat besar pengaruhnya untuk mencapai belajar yang mandiri. Di jurusan Pendidikan Teknik Elektronika masih kurang dalam hal menyediakan Media ajar mata kuliah pengantar pendidikan kejuruan. Sehingga penelitian tentang "Pengembangan Media Ajar Mata Kuliah pengantar pendidikan kejuruan Di Jurusan Pendidikan Teknik Elektronika 
Universitas Negeri Makassar" perlu dilakukan.

Berdasarkan latar belakang permasalahan yang telah dikemukakan diatas, pengembangan Media ajar mata kuliah pengantar pendidikan kejuruan dipandang penting, karena permasalahan terkait yang dapat diidentifikasikan adalah: 1) Kebutuhan yang mendesak bagi dosen dan mahasiswa akan Media ajar mata kuliah pengantar pendidikan kejuruan untuk mahasiswa Jurusan Pendidikan Teknik Elektronika dalam rangka memenuhi tuntutan pembelajaran di Jurusan Pendidikan Teknik Elektronika; 2) Terbatasnya Media ajar mata kuliah pengantar pendidikan kejuruan yang relevan dengan silabus yang sedang berlaku; 3) Pembelajaran pengantar pendidikan kejuruan memerlukan Media ajar yang sesuai dengan karakteristik mahasiswa jurusan Pendidikan Teknik Elektronika; 4) Mahasiswa belum memaksimalkan penggunaan Media ajar mata kuliah pengantar pendidikan kejuruan sebagai sumber belajar

Berdasarkan latar belakang dan identifikasi masalah tersebut, penelitian dibatasi pada bagaimana mengembangkan Media ajar mata kuliah pengantar pendidikan kejuruan serta uji kelayakan dan respon penggunaan dalam pembelajaran, khususnya buku ajar mata kuliah pengantar pendidikan kejuruan sebagai sumber belajar untuk mahasiswa jurusan Pendidikan Teknik Elektronika. Tujuan Pengembangan Adalah: 1) Untuk mengetahui tahapan pengembangan Media ajar pada mata kuliah pengantar pendidikan kejuruan di Jurusan Pendidikan Teknik Elektronika di Universitas Negeri Makassar; 2) Untuk mengetahui kelayakan Media ajar pada mata kuliah pengantar pendidikan kejuruan di Jurusan
Pendidikan Teknik Elektronika di Universitas Negeri Makassar.

Adapun spesifikasi pengemabangan Media ajar pada mata kuliah pengantar pendidikan kejuruan yang akan dibuat adalah berupa: 1) Kontrak Kuliah adalah kesepakatan yang mengikat antara dosen dan mahasiswa mengenai berbagai aspek pembelajaran melalui interaksi dan pengelolaan pembelajaran secara efektif dengan sanksi (secara edukatif); 2) Silabus adalah rencana pembelajaran pada suatu mata kuliah atau tema tertentu yang mencakup kompetensi inti, kompetensi dasar, materi pembelajaran dan sumber belajar pada suatu lingkungan belajar; 3) Rencana Pembelajaran Semester (RPS) pada dasarnya merupakan suatu bentuk prosedur dan manajemen pembelajaran untuk mencapai kompetensi dasar yang telah ditetapkan dalam standar isi (standar kurikulum); 4)Bahan ajar merupakan informasi, alat dan teks yang diperlukan untuk guru/instruktur untuk perencanaan dan penelaahan implementasi pembelajaran.

\section{METODE PENELITIAN}

Model penelitian dan pengembangan yang digunakan pada pada penelitian ini mengacu pada Model Pengembangan Instruksional (MPI) oleh Atwi Suparman. Langkahlangkah penelitian dan pengembangannya meliputi (1) Tahap mengidentifikasi yang terdiri dari; mengidentifikasi kebutuhan instruksional, menulis tujuan instruksional, mengidentifikasi perilaku dan karakteristik awal peserta didik, dan melakukan analisis instruksional, (2) Tahap mengembangkan yang terdiri dari menyusun strategi instruksional, menyusun alat penilaian hasil belajar dan mengembangkan bahan instruksional dan (3) Tahap mengevaluasi yang terdiri dari 
menyusun desain dan melaksanakan evaluasi formatif.

Tahap mengidentifikasi dilakukan melalui kegiatan observasi dan wawancara dosen. Tahap mengembangkan melakukan penilaian hasil belajar dapat digunakan untuk mengukur seberapa jauh tingkat keberhasilan peserta didik dalam mencapai tujuan instruksional. Strategi instruksional yang telah dikembangkan, alat penilaian hasil belajar yang telah disusun, dan karakteristik awal peserta didik yang telah diidentifikasi merupakan resep untuk mengembangkan Media instruksional. Media instruksional yang dikembangkan berbentuk Media ajar mata kuliah pengantar pendidikan kejuruan. Setelah Media instruksional dikembangkan, peneliti perlu mengajukan pertanyaan kepada dirinya sendiri. Apakah Media ajar yang telah dikembangkan melalui proses yang sistematik itu benar-benar berkualitas? Bila Media itu digunakan apakah efektif dalam mencapai tujuannya.? Apakah Media ajar itu masih perlu direvisi agar peserta didik dan pengajar dapat menggunakan dengan nyaman dan menyenangkan? Ketiga pertanyaan itu perlu dijawab dengan melakukan evaluasi formatif untuk mencari kekurangannya dan kemudian melakukan revisi untuk meningkatkan kualitasnya.

Pada penelitian dan pengembangan ini validasi Media ajar mata kuliah pengantar pendidikan kejuruan dilakukan dalam dua tahap. Tahap pertama yaitu validasi desain dan tahap kedua yaitu validasi ahli konten. Data yang dikumpulkan berupa data kuantitatif. Data kuantitatif diperoleh dari hasil kuisioner validasi. Data kuantitatif mendeskripsikan tentang: Kelayakan Media ajar. Data tersebut diperoleh dari dosen ahli desain, dosen ahli konten Media ajar di jurusan Pendidikan Teknik Elektronika.

\section{HASIL PENELITIAN}

Hasil penelitian dan pengembangan ini berupa kontrak kuliah, silabus, RPS (Rencana Pembelajaran Semester), dan Media ajar mata kuliah pengantar pendidikan kejuruan. Media instruksional yang dihasilkan dari penelitian ini adalah Media ajar yang berupa buku ajar mata kuliah pengantar pendidikan kejuruan. Buku ajar ini dilengkapi dengan subcapaian pembelajaran, materi pembelajaran yang terkait, rangkuman, tugas setiap materi.

Halaman sampul bagian depan terdiri dari judul, tim penyusun, logo, dan gambar. Sedangkan sampul bagian belakang dibuat identitas buku ajar. Gambar yang dipilih disesuaikan dengan materi isi dari buku ajar pengantar pendidikan kejuruan. Bagian isi buku ini terdapat 8 bab yang terdiri dari; pengertian pendidikan dan ilmu pendidikan dan unsur-unsur pendidikan, landasan dan asas pendidikan kejuruan vokasi dan aliran-aliran pendidikan, sistem pendidikan nasional berlandaskan pendidikan kejuruan dan pendidikan pengembangan pendidikan kejuruan, pandangan pendidikan tentang manusia sebagai animal Educandum, landasan teori pendidikan dan filosofi dan latar belakang kelembagaan pendidikan vokasi (kejuruan), karakteristik pembelajaran kejuruan dan merumuskan tujuan pembelajaran, strabilitas dan pendekatan saintifik dalam pembelajaran kejuruan dan penyelenggaraan pendidikan vokasi dan kejuruan, strategi pembelajaran TVET. Bagian isi bab terdapat beberapa bagian yaitu bagian awal, uraian materi, rangkuman, tugas. Bagian untuk setiap awal bab terdapat judul bab dan subcapaian pembelajaran.

Tahap akhir dari suatu proses pengembangan instruksional adalah evaluasi. Hasilnya akan menjadi dasar pengambilan keputusan tentang dua hal, 
yaitu: seberapa layak Media ajar yang dikembangkan dan bagian mana yang masih lemah sehingga perlu direvisi. Berikut tahapan evaluasi formatif yang akan dilakukan oleh peneliti:

Setelah draft buku ajar selesai disusun. Draft buku ajar dilakukan review atau validasi oleh ahli desain dan ahli konten. Kedua ahli ini akan memberikan komentar atau masukan terhadap buku ajar mata kuliah pengantar pendidikan kejuruan ini dari sudut pandang keahlian masing-masing. Setelah dilakukan proses validasi atau review, ada beberapa masukan dari kedua ahli. Maka buku ajar ini perlu dilakukan revisi dibeberap bagian.

1) Revisi Ahli Desain

Revisi yang diberikan ahli desain adalah sampul disesuaikan ilustrasi dari isi materi pengantar pendidikan kejuruan.

\section{Hasil Validasi Media Ajar Ahli Desain}

Data hasil evaluasi ahli desain pada tabel di atas dapat dilihat aspek bentuk dan ukuran Media ajar memperoleh rata-rata 3,83 dalam kategori baik (layak), aspek organisasi memperoleh rata-rata 3,57 dalam kategori cukup baik (layak), aspek daya tarik memperoleh rata-rata 3,75 dalam kategori baik (layak), aspek format memperoleh rata-rata 3,88 dalam kategori baik (layak), dan aspek konsistensi memperoleh rata-rata 3,57 dalam kategori cukup baik (layak). Hasil evaluasi ahli desain di cari total rata-rata maka di peroleh 3,72 dalam kategori "baik (layak)".

Hasil penelitian dalam bentuk diagram batang terlihat sebagai berikut:

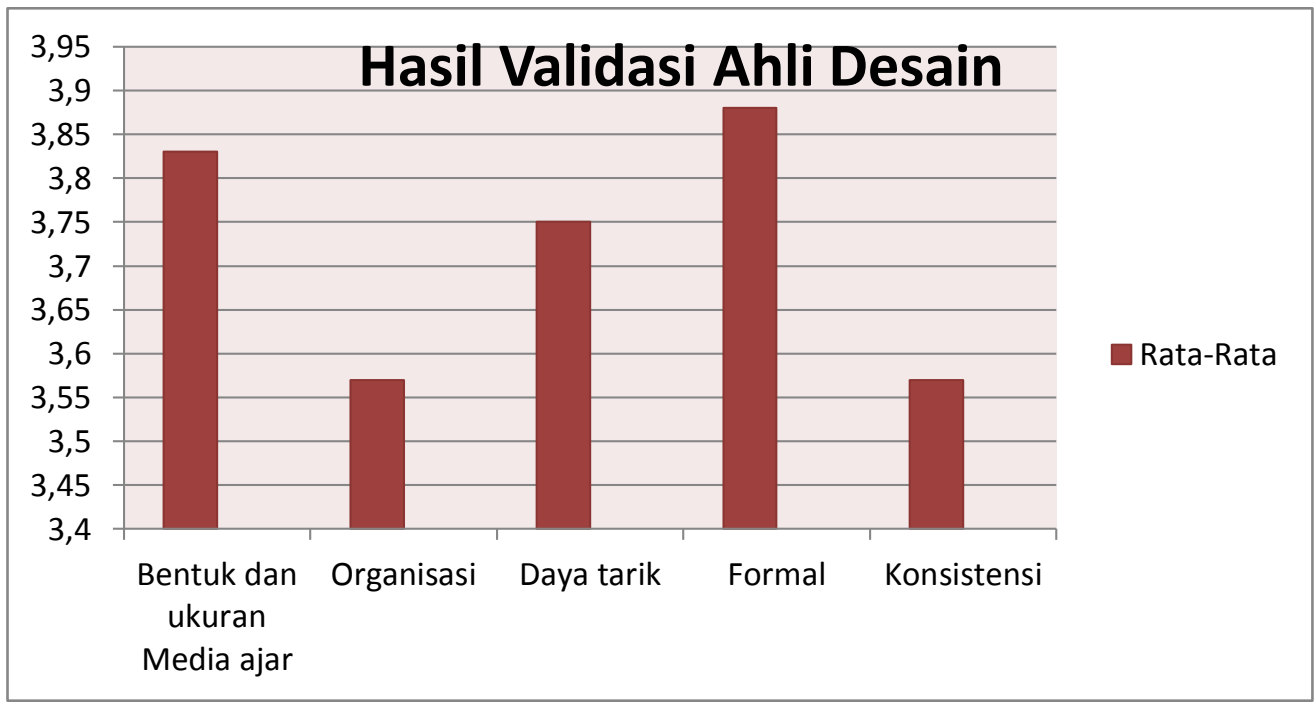

Gambar 1. Hasil Validasi Ahli Desain

Hasil Validasi Media Ajar Ahli Konten

Data hasil evaluasi ahli konten pada tabel diatas dapat dilihat aspek Self Instructional memperoleh rata-rata 2,81 dalam kategori cukup baik (layak), aspek Self Contained memperoleh ratarata 2,83 dalam kategori cukup baik (layak), aspek Stand Alone memperoleh rata-rata 3 dalam kategori cukup baik (layak), Stand adaptive memperoleh rata-rata 3 dalam kategori cukup baik (layak), dan user friendly memperoleh 2,71 dalam kategori cukup baik (layak). Hasil evaluasi ahli konten di cari total rata-rata maka di peroleh 2,87 dalam kategori "cukup baik (layak)".

Hasil penelitian dalam bentuk diagram batang terlihat sebagai berikut: 


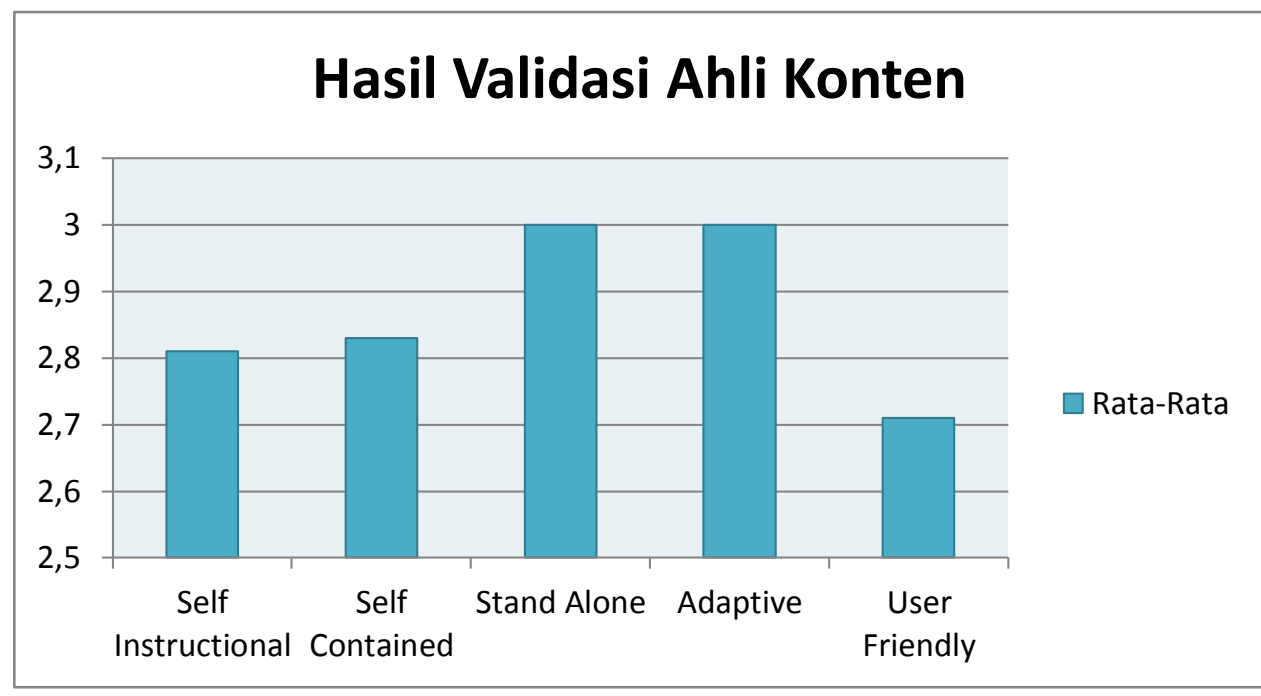

Gambar 2 Hasil Validasi Ahli Konten

\section{Pembahasan}

Penelitian ini dilakukan untuk mengembangkan Media ajar pengantar pendidikan kejuruan dan diuji tingkat kelayakan oleh ahli desain dan ahli konten. Desain Media ajar pengantar pendidikan kejuruan yang dikembangkan pada penelitian ini adalah buku ajar pengantara pendidikan kejuruan. Proses pengembangan Media ajar ini mengacu pada model pengembangan instruksional yaitu tahap mengidentifikasi, tahap mengembangkan dan tahap evaluasi (Atwi, 2012:92).

Menurut hasil penelitian, dalam validasi Media ajar pengantar pendidikan kejuruan agar dapat memperoleh penilaian yang bagus maka Media ajar pengantar pendidikan kejuruan harus dapat memenuhi aspek dari setiap ahli desain dan ahli konten. Sehingga perlu diperhatikan antara materi yang akan ditulis dengan silabus yang digunakan apakah sudah tepat. Kemudian penempatan porsi antara gambar dan tulisan seimbang agar mahasiswa paham saat belajar mandiri dengan menggunakan Media ajar pengantar pendidikan kejuruan.

Berdasarkan analisis data hasil penelitian diperoleh hasil-hasil penelitian yang dapat dijabarkan dalam pembahasan sebagai berikut:

\section{Ahli desain}

Berdasarkan penelitian ahli desain, kelayakan Media ajar pengantar pendidikan kejuruan di nyatakan dalam kategori "baik (layak)".. Hal ini dapat diartikan bahwa ahli desain menyatakan bahwa buku ajar mata kuliah pengantar pendidikan kejuruan dalam kategori sangat layak digunakan sebagai Media ajar mata kuliah pengantar pendidikan kejuruan. Namun walaupun begitu ada bagian yang harus direvisi sesuai dari saran dari ahli desain. Bagian yang direvisi yaitu sampul harus sesuai dengan judul Media ajar.

\section{Ahli konten}

Berdasarkan penilaian ahli konten, kelayakan Media pengantar pendidikan kejuruan di nyatakan dalam kategori "cukup baik (layak)". Hal ini dapat diartikan bahwa ahli konten menyatakan bahawa buku ajar mata kuliah pengantar pendidikan kejuruan layak digunakan sebagai Media ajar mata kuliah pengantar pendidikan kejuruan. Namun walaupun begitu ada bagian yang harus direvisi sesuai dari saran dari ahli konten. Bagian yang 
direvisi yaitu: Perbaikan catatan dalam buku, kalimatnya diperbaiki.

\section{KESIMPULAN}

Berdasarkan hasil penelitian dan pembahasan yang telah diuraikan, serta melihat permasalahan dari rumusan masalah, maka dapat ditarik kesimpulan sebagi berikut:

1. Pengembangan Media ajar mata kuliah pengantar pendidikan kejuruan memberikan output berupa buku ajar pengantar pendidikan kejuruan yang dilakukan melalui 3 tahap yaitu (a) tahap mengidentifikasi, (b) tahap mengembangkan, dan (c) tahap evaluasi. Hasil tahap mengidentifikasi adalah deskrispsi analisis identifikasi masalah, analisis karakteristik peserta didik, dan analisis sumber belajar. Hasil tahap mengembangkan adalah analisis identifikasi tujuan, penentuan metode pembelajaran, dan pembuatan Media ajar mata kuliah pengantar pendidikan kejuruan. Tahap evaluasi meliputi uji coba Media ajar mata kuliah pengantar pendidikan kejuruan, analisis hasil validasi, dan implementasi.

2. Penilaian Media ajar mata kuliah pengantar pendidikan kejuruan berdasarkan penilaian ahli desain dan ahli konten. Penilaian ahli desain dalam kategori baik (layak), sedangkan ahli konten dalam kategori cukup baik (layak).

\section{DAFTAR PUSTAKA}

Abdul Hadis dan Nurhayati B. 2012. Manajemen Mutu Pendidikan. Bandung: Alfabeta.
Andi Prastowo. 2011. Panduan Kreatif Membuat Bahan Ajar Inovatif. Yogyakarta: Diva Press

Azwar, Saifuddin. 2012. Penyusunan Skala Psikologi. Yogyakarta: Pustaka Belajar

Anas Arfandi, \& Taufiq Natsir. 2014. Silabus Pengantar Pendidikan Kejuruan. Universitas Negeri Makassar.

Chomsin S Widodo dan Jasmadi. 2008. Panduan Menyusun Bahan Ajar Berbasis Kompetensi. Jakarta: PT Alex Media Kompetindo.

Daryanto dan Aris Dwicahyono. 2014. Pengembangan Perangkat Pembelajaran (silabus, RPP, PHB, Bahan Ajar). Yogyakarta: Gava Media.

Depdiknas. 2006. Kurikulum Standar Isi 2006. Badan Standar Nasional Pendidikan.

Endang Mulyatiningsih. 2014. Metode Penelitian Terapan Bidang Pendidikan. Bandung: Alfabeta.

Emzir. 2011. Metodologi Penelitian Pendidikan Kuantitatif \& Kualitatif. Jakarta: PT Raja Grafindo Persada.

Imas Kurniasih dan Berlin Sani. 2014. Panduan Membuat Bahan Ajar (Buku Teks Pelajaran) Sesuai Dengan Kurikulum 2013. Surabaya: Kata Pena.

Kitao, Kenji. 1997. "Selecting and Developing Teaching/Learning Materials". The Internet 
TESL Journal Vol. IV, No 4, April 1997 (http://iteslj.org/Articles/Kita o-Materials.html). Pada tanggal 1 November 2016 jam 16.00 WITA.

M. Atwi Suparman. 2012. Desain Instruksional Modern. Jakarta: Erlangga.

Republik Indonesia. 2005. Peraturan Menteri Pendidikan Nasional No. 65 Tahun 2013 Tentang Standar Proses. Jakarta: Sekretariat Negara RI.

Republik Indonesia. 2005. Peraturan Pemerintah No. 19 Tahun 2005 Tentang Standar Nasional Pendidikan. Jakarta: Sekretariat Negara RI.

Sugiyono. 2014. Metode Penelitian Pendidikan Pendekatan Kuantitatif, Kualitatif, dan $R$ \& $D$. Bandung: Alfabeta

Sugiyono. 2016. Metode Penelitian Pendidikan (Pendekatan Kuantitatif, Kualitatif, dan $R \& D)$. Bandung: Alfabeta.

Umar Tirtaraharja dan S.L. Lasulo. 2010. Pengantar pendidikan, edisi revisi. Jakarta: Dirjen Dikti 